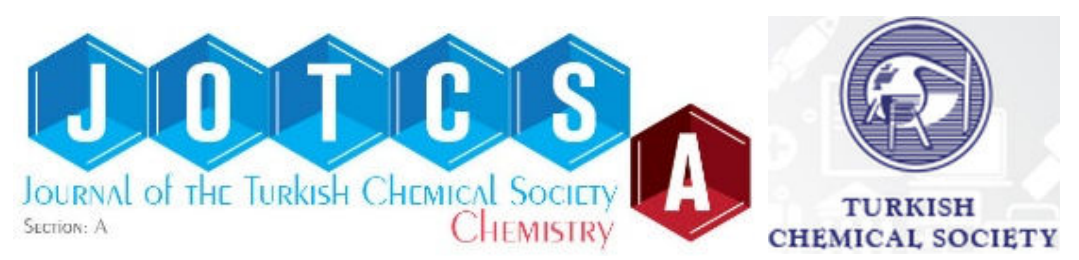

\title{
Comparison of Catalytic Activities both for Selective Oxidation and Decomposition of Ammonia over Fe/HZ $\beta$ Catalyst
}

\author{
Yeliz Durak-Çetin ${ }^{1,2 *}$, Alper Sarıoğlan ${ }^{1}$, Hasancan Okutan ${ }^{2}$ \\ ${ }^{1}$ TÜBİTAK Marmara Research Center, Energy Institute, P.0.21, 41470, Gebze/KOCAELI, \\ TURKEY \\ ${ }^{2}$ Faculty of Chemical and Metallurgical Engineering, Istanbul Technical University, 34469, \\ Maslak/ISTANBUL, TURKEY
}

\begin{abstract}
Ammonia is one of the syngas contaminants that must be removed before using the syngas downstream applications. The most promising hot-gas clean-up techniques of ammonia are selective catalytic oxidation (SCO) and catalytic decomposition. In this study, the catalytic activities over Zeolite $\mathrm{H} \beta$-supported iron catalyst $(\mathrm{Fe} / \mathrm{HZ} \beta)$ were compared both for the two catalytic routes. For SCO experiments, temperature $\left(300-550{ }^{\circ} \mathrm{C}\right), \mathrm{O}_{2}(2000-6000 \mathrm{ppmv})$ and $(0-10 \%) \mathrm{H}_{2}$ concentrations were investigated with the presence of $800 \mathrm{ppm}$ of $\mathrm{NH}_{3}$ in each final gas mixture. In the second route, catalytic ammonia decomposition experiments were carried out with $\mathrm{H}_{2}$ in balance $\mathrm{N}_{2}(0-30 \%)$ containing $800 \mathrm{ppm}$ of $\mathrm{NH}_{3}$ at $700{ }^{\circ} \mathrm{C}$ and $800{ }^{\circ} \mathrm{C}$. In the $\mathrm{SCO}, \mathrm{NH}_{3}$ conversions were increased with increasing reaction temperatures with the absence of $\mathrm{H}_{2}$ in the reaction mixture. With $10 \% \mathrm{H}_{2}$, it was shown that $\mathrm{NH}_{3}$ conversions increased with decreasing the reaction temperature. This was interpreted as the competing $\mathrm{H}_{2}$ and $\mathrm{NH}_{3}$ oxidations over the catalyst. On the other hand, in the catalytic decomposition, thermodynamic equilibrium conversion of almost $100 \%$ was attained at both 700 and $800{ }^{\circ} \mathrm{C}$. Upon $\mathrm{H}_{2}$ addition, all conversions decreased. The decrease in conversion seemed to be linear with inlet hydrogen concentration. Hydrogen was seen to inhibit the decomposition of ammonia. It was shown that $\mathrm{Fe} / \mathrm{HZ} \beta$ catalyst is better to use for catalytic decomposition of $\mathrm{NH}_{3}$ in syngas rather than $\mathrm{SCO}$ of $\mathrm{NH}_{3}$ in spite of higher reaction temperatures needed in the decomposition reaction.
\end{abstract}

Keywords: Ammonia; decomposition; selective catalytic oxidation (SCO); hot-gas cleanup.

Submitted: July 01, 2016. Revised: November 11, 2016. Accepted: November 18, 2016.

Cite this: Durak-Çetin Y, Sarığlan A, Okutan H. Comparison of Catalytic Activities both for Selective Oxidation and Decomposition of Ammonia over Fe/HZ $\beta$ Catalyst. JOTCSA. 2017;4(1):227-42.

DOI: To be assigned.

*Corresponding author. E-mail: yeliz.durak@tubitak.gov.tr 
Durak-Çetin, Sarıoğlan and Okutan, JOTCSA. 2017; 4(1): 227-242. RESEARCH ARTICLE

\section{INTRODUCTION}

Gasification is a thermochemical conversion technology applied for the production of synthetic fuels and chemicals from coal and biomass. A syngas containing $\mathrm{H}_{2}$ and $\mathrm{CO}$ is released as a result of gasification reactions [1]. The integrated gasification combined cycle (IGCC) uses the syngas to meet heat and power demand. Synthetic fuels and chemicals are catalytically produced from this syngas through the Fischer-Tropsch (FT) process as well. Before FT reaction, the syngas should be cleaned to remove all nitrogenous $\left(\mathrm{NH}_{3}, \mathrm{HCN}\right)$ and sulfurous $\left(\mathrm{H}_{2} \mathrm{~S}, \mathrm{COS}\right)$ pollutants in ppm level, otherwise they lead to the poisoning of the FT catalysts shortly [2-3]. While $\mathrm{NH}_{3}$ concentrations can be reached up to $10000 \mathrm{ppmv}$ in syngas as a function of the nitrogen content of the solid fuel [4], its threshold level is below 1 ppmv [5]. $\mathrm{NH}_{3}$ removal can be achieved via three different ways; scrubbing, thermal incineration, and catalytic routes. In the scrubbing as a wet process, the waste gas is washed with a chemical solution and it is necessary to treat the waste water later. In the thermal incineration, ammonia is thermally burnt and $\mathrm{NO}_{x}$ is formed. In the catalytic processes; $\mathrm{NH}_{3}$ is passed through a column packed with a catalyst. In the one way of catalytic routes, $\mathrm{NH}_{3}$ in the syngas can oxidatively be converted into harmless nitrogen and water in an exothermic manner. This process is called as selective catalytic oxidation (SCO). In the second way of the catalytic route, $\mathrm{NH}_{3}$ can be decomposed into hydrogen and nitrogen via the non-oxidative endothermic reaction (Reaction 1 ) [6].

$$
2 \mathrm{NH}_{3} \leftrightarrow \mathrm{N}_{2}+3 \mathrm{H}_{2}
$$

Catalytic decomposition of ammonia occurs on a variety of transition metals and natural minerals. Many metals, mainly $\mathrm{Fe}, \mathrm{Co}, \mathrm{Ni}, \mathrm{Ru}, \mathrm{Rh}, \mathrm{Pd}, \mathrm{Os}, \mathrm{Ir}, \mathrm{Pt}, \mathrm{W}$, and $\mathrm{Cu}$, have been tested for ammonia decomposition and it was found that ruthenium is the most active among them $[7,8]$. The cost of ruthenium is a major concern for commercial utilizations. Therefore, iron based catalysts have been investigated for $\mathrm{NH}_{3}$ decomposition [9-12]. In the review study of Hongrapipat et al., it was stated that ferrous minerals are promising catalysts for $\mathrm{NH}_{3}$ decomposition [4]. For example iron sinter, iron pellets, and ferrous dolomite all catalyze the decomposition of $2500 \mathrm{ppm} \mathrm{NH}$ in product gas from a peat fueled gasifier at $900^{\circ} \mathrm{C}$ and about $85 \%$ conversions were achieved [9]. In a study by Xu et al., pyrolysis chars from low rank coals were tested and found that the inherently present $\mathrm{Fe}$ and $\mathrm{Ca}$ minerals in the coal chars were responsible for their activities towards ammonia decomposition [11]. Ohtsuka and co-workers demonstrated that low-valued iron ore, namely limonite, rich in goethite $(\mathrm{a}-\mathrm{FeOOH})$ can achieve the almost complete decomposition of $2000 \mathrm{ppm} \mathrm{NH}$ in inert atmosphere at $500^{\circ} \mathrm{C}$. They also discovered that the presence of phosphorous in the carbon-supported Fe catalysts could greatly promote 
catalytic decomposition of ammonia [13-14]. But in these studies, typically temperatures above $850^{\circ} \mathrm{C}$ were needed when the reaction was run in the presence of fuel gases. The catalytic performance of the catalysts was severely affected by the fuel gases. The requisite of high temperatures is the drawback of decomposition of $\mathrm{NH}_{3}$. On the other hand, selective catalytic oxidation (SCO) of ammonia is one of the most efficient technologies for ammonia removal from oxygen-containing waste gases. SCO of ammonia involves the controlled addition of an oxidizer $\left(\mathrm{O}_{2}, \mathrm{NO}, \mathrm{NO} / \mathrm{O}_{2}\right)$ to the gasification gas to quantitatively and selectively transform $\mathrm{NH}_{3}$ into $\mathrm{N}_{2}$ and $\mathrm{H}_{2} \mathrm{O}$. The catalytic oxidation of ammonia usually occurs between $400-600{ }^{\circ} \mathrm{C}$ and depending on operating conditions and the type of catalysts used, can proceed in the three principal reactions (Reactions 2-4).

$$
\begin{gathered}
4 \mathrm{NH}_{3}+3 \mathrm{O}_{2} \rightarrow 2 \mathrm{~N}_{2}+6 \mathrm{H}_{2} \mathrm{O}+302 \mathrm{kcal} \\
4 \mathrm{NH}_{3}+6 \mathrm{NO} \rightarrow 5 \mathrm{~N}_{2}+6 \mathrm{H}_{2} \mathrm{O} \\
4 \mathrm{NH}_{3}+4 \mathrm{NO}+\mathrm{O}_{2} \rightarrow 4 \mathrm{~N}_{2}+6 \mathrm{H}_{2} \mathrm{O}
\end{gathered}
$$

But in the presence of $\mathrm{O}_{2}$, undesirable competing reactions with Reaction 2 can occur and NOx emissions can be released (Reactions 5-7) [15-16].

$$
\begin{gathered}
4 \mathrm{NH}_{3}+4 \mathrm{O}_{2} \rightarrow 2 \mathrm{~N}_{2} \mathrm{O}+6 \mathrm{H}_{2} \mathrm{O}+264 \mathrm{kcal} \\
4 \mathrm{NH}_{3}+5 \mathrm{O}_{2} \rightarrow 4 \mathrm{NO}+6 \mathrm{H}_{2} \mathrm{O}+216 \mathrm{kcal} \\
4 \mathrm{NH}_{3}+7 \mathrm{O}_{2} \rightarrow 4 \mathrm{NO}_{2}+6 \mathrm{H}_{2} \mathrm{O}
\end{gathered}
$$

Or alternatively $\mathrm{N}_{2} \mathrm{O}$ emission may be formed through Reaction 8 :

$$
4 \mathrm{NO}+4 \mathrm{NH}_{3}+3 \mathrm{O}_{2} \rightarrow 4 \mathrm{~N}_{2} \mathrm{O}+6 \mathrm{H}_{2} \mathrm{O}
$$

When the ammonia removal from gasification gas is needed, it is more convenient to use oxygen as oxidant rather than nitrogen oxides. The oxygen that used as oxidant on SCO of ammonia should not affect the syngas composition which contains combustible gases like $\mathrm{CO}, \mathrm{H}_{2}, \mathrm{CH}_{4}$, etc. Also it is undesirable to convert ammonia to nitrogen oxides. In the patented study of $\mathrm{Y}$. Shioya et al., it is said that the optimal $\mathrm{O}_{2}$ amount should be two moles or more $\mathrm{O}_{2}$ for one mole of ammonia [17]. Catalysts used for SCO of ammonia are classified in three groups: One is metallic catalysts, the other is transition metal catalysts and their oxides $\left(\mathrm{CO}_{3} \mathrm{O}_{4}, \mathrm{MnO}_{2}\right.$ or $\mathrm{V}_{2} \mathrm{O}_{5}, \mathrm{Al}_{2} \mathrm{O}_{3}$ supported $\mathrm{Ni}, \mathrm{Fe}$ and $\mathrm{Mn}, \mathrm{CuO} / \mathrm{Al}_{2} \mathrm{O}_{3}$ or $\mathrm{Fe}_{2} \mathrm{O}_{3}-\mathrm{Al}_{2} \mathrm{O}_{3}, \mathrm{Fe}_{2} \mathrm{O}_{3}-\mathrm{TiO}_{2}, \mathrm{Fe}_{2} \mathrm{O}_{3}-\mathrm{ZrO}_{2}$ etc.), and zeolites. Precious metal catalysts (Pt, $\mathrm{Pd}$, $\mathrm{Ir}, \mathrm{Ru}, \mathrm{Ag}$, etc.) show high activity at temperatures lower than $200{ }^{\circ} \mathrm{C}$. On the other hand, transition metal oxide catalysts are active at higher temperatures ( $<400{ }^{\circ} \mathrm{C}$ ) than precious catalysts but show higher selectivity to $\mathrm{N}_{2}$. Another potential group is transition metal oxide impregnated zeolite (ZSM5, Y, mordenite, beta, ferrierite, chabazite, etc.) 
catalysts. Zeolite supported catalysts are active at relatively high temperatures [15]. High acidity ZSM5, Zeolite Beta and Zeolite $Y$ supported iron catalysts were tried at 350, 400 and $450{ }^{\circ} \mathrm{C}$ and it was seen that with the increase in temperature $\mathrm{NH}_{3}$ conversion and $\mathrm{N}_{2}$ selectivity increased as well. The highest ammonia conversions (95-100\%) were achieved at $450{ }^{\circ} \mathrm{C} .450{ }^{\circ} \mathrm{C}$ is a relatively low temperature when compared with catalytic ammonia decomposition temperatures which are typically $750-850{ }^{\circ} \mathrm{C}$. High iron content of catalysts, low $\mathrm{Si} / \mathrm{Al}$ ratio of zeolites and low ammonia concentration is advantageous cases in selective catalytic oxidation of ammonia [18]. A detailed PhD study on SCO of ammonia showed that activity of different active metals at $300^{\circ} \mathrm{C}$ decrease in this order: $\mathrm{Pt}>\mathrm{Pd}>\mathrm{Cu}>\mathrm{Ag}>\mathrm{Au}>\mathrm{Fe}>\mathrm{W}>\mathrm{Ti}$. High ammonia conversions and $\mathrm{N}_{2}$ selectivities can be achieved with copper based catalysts at atmospheric pressure. But at high pressures, the ammonia conversion can decrease under 30\% [19]. In this study, the catalytic activities of Zeolite $\mathrm{H} \beta$ supported iron catalyst $(\mathrm{Fe} / \mathrm{HZ} \beta$ ) were compared both for the selective catalytic oxidation and catalytic decomposition of 800 ppmv ammonia.

\section{MATERIALS AND METHODS}

Zeolite support, namely Zeolite $\mathrm{H} \beta$, was supplied by Zeolyst International Incorporation. The silica-to-alumina ratio of the zeolite was 38. Wet impregnation method was used to prepare the catalyst. Zeolite $\mathrm{H} \beta$ was in ammonium form prior to impregnation. For preparation of the catalyst, iron nitrate $\left(\mathrm{Fe}\left(\mathrm{NO}_{3}\right)_{3} .9 \mathrm{H}_{2} \mathrm{O}\right.$, Alfa Aesar) was dissolved in a minimum volume of water and the zeolite was added to the solution so as to achieve a nominal iron content of $10 \%$ by weight. The slurry was subsequently dried at $90{ }^{\circ} \mathrm{C}$ overnight. Zeolite-supported iron catalyst was labeled as $\mathrm{Fe} / \mathrm{HZ} \beta$ through the article. Chemical analysis of the catalyst was performed using inductively coupled plasma spectroscopy (Perkin Elmer Optima 2100 ICP-OES). Iron content of the synthesized catalyst was analyzed to be $12.96 \%$. Fe/HZ $\beta$ catalyst was milled and sieved under 500 $\mu \mathrm{m}$ before the catalytic experiments. A $5 \mathrm{cc}(\sim 3 \mathrm{~g})$ sample of the dry catalyst powder was placed in a vertical stainless steel reactor with 310 grade $(17 \mathrm{~mm}$ i.d.), calcined in dry air at $420^{\circ} \mathrm{C}$ for 5 hours and reduced under pure hydrogen flow at the same temperature for 10-12 hours as previously explained in detail [20]. After the reduction of the catalyst, different gas mixtures composed of 800 ppmv ammonia were prepared. For selective catalytic oxidation experiments, 2000-6000 ppmv $\mathrm{O}_{2}$ and $0-10 \% \quad \mathrm{H}_{2}$ concentrations were prepared in balance with $\mathrm{N}_{2}$ at the temperatures of $300-550{ }^{\circ} \mathrm{C}$. For decomposition experiments; $0-10-20-30 \% \mathrm{H}_{2}$ and balance $\mathrm{N}_{2}$ were flown over the catalyst bed for $5 \mathrm{~h}$ at the temperatures of $700{ }^{\circ} \mathrm{C}$ and $800^{\circ} \mathrm{C}$ and a GHSV of $60000 \mathrm{~h}^{-1}$. Reaction products were analyzed in line using a UV-Vis $\mathrm{NH}_{3}$ Analyzer and a Mass 
Durak-Çetin, Sarıoğlan and Okutan, JOTCSA. 2017; 4(1): 227-242. RESEARCH ARTICLE

Spectrometer. $\mathrm{NH}_{3}$ conversion to hydrogen was calculated from the measured $\mathrm{NH}_{3}$ in the product stream, reaction stoichiometry, and the differential reactor assumption, as $\mathrm{P}_{\mathrm{NH} 3}$ to $\mathrm{H} 2 / \mathrm{P}_{\mathrm{NH} 3}$, inlet. $\mathrm{NO}_{x}$ concentrations were measured with off-line Analytic Jena multi $\mathrm{EA}^{\circledR} 5000$ Total Nitrogen (TN) measuring device equipped with Nitrogen Chemiluminescence Dedector (NCD).

\section{RESULTS AND DISCUSSION}

\section{Comparison of Catalytic Activities Under N2 Atmosphere}

Approximately $3 \mathrm{~g}(\sim 5 \mathrm{cc})$ of $\mathrm{Fe} / \mathrm{HZ} \beta$ catalyst was charged to the reactor and calcined with air at $420^{\circ} \mathrm{C}$ for $5 \mathrm{~h}$. Then the reduction procedure was started by shifting to pure $\mathrm{H}_{2}$ flow at the same temperature and the catalyst was reduced for $10 \mathrm{~h}$. In the first set of experiments (selective catalytic reduction labelled as SCO), a gas mixture consisting of 800 ppm NH, 2000 and 4000 ppm $\mathrm{O}_{2}$ and balance $\mathrm{N}_{2}$ was flown over the catalyst with a gas flow rate of $5 \mathrm{~L} / \mathrm{min}\left(\mathrm{GHSV}=60,000 \mathrm{~h}^{-1}\right)$. SCO reaction tests were conducted at 300, $350,400,450$ and $500{ }^{\circ} \mathrm{C}$. In the second set of experiments (catalytic decomposition), a gas mixture of $800 \mathrm{ppm} \mathrm{NH}$ and balance $\mathrm{N}_{2}$ was flown over the reduced catalyst with the same gas flow rate and catalytic decomposition of $\mathrm{NH}_{3}$ was carried out at $700{ }^{\circ} \mathrm{C}$ and 800 ${ }^{\circ} \mathrm{C}$ in the absence of $\mathrm{O}_{2}$. In the last set, blank reactor tests were conducted with the same gas mixture used for catalytic decomposition of $\mathrm{NH}_{3}$. Reaction products were analyzed in line using a UV-Vis $\mathrm{NH}_{3}$ analyzer and a mass spectrometer. Calculated $\mathrm{NH}_{3}$ conversions versus reaction temperature were plotted in Figure 1.

For the first set of SCO experiment, $4 \%$ of ammonia conversion (based on UV-Vis measurements) was achieved at $300{ }^{\circ} \mathrm{C}$ in the presence of $2000 \mathrm{ppm} \mathrm{O}$. When the reaction temperature was increased stepwise to $500^{\circ} \mathrm{C}, \mathrm{NH}_{3}$ conversions were steadily increased. $100 \%$ ammonia conversion was reached at $500{ }^{\circ} \mathrm{C}$ under SCO conditions. SCO tests were conducted at 350 and $400{ }^{\circ} \mathrm{C}$ by increasing the oxygen concentration from $2000 \mathrm{ppm}$ to $4000 \mathrm{ppm}$ to see the effect of $\mathrm{O}_{2}$ on $\mathrm{NH}_{3}$ conversion. At $350{ }^{\circ} \mathrm{C}$, ammonia conversions of $12.5 \%$ and $8.8 \%$ at the reactor exit were obtained with the presence of 2000 and $4000 \mathrm{ppm} \mathrm{O}$, respectively. When the reaction temperature was increased to $400{ }^{\circ} \mathrm{C}$, while $\mathrm{NH}_{3}$ conversion was reached to $31.2 \%$ in the presence of $2000 \mathrm{ppm} \mathrm{O}$, it was $41.2 \%$ for $4000 \mathrm{ppm} \mathrm{O}$. It was shown that higher $\mathrm{NH}_{3}$ conversions could be achieved with increasing $\mathrm{O}_{2}$ concentrations. 


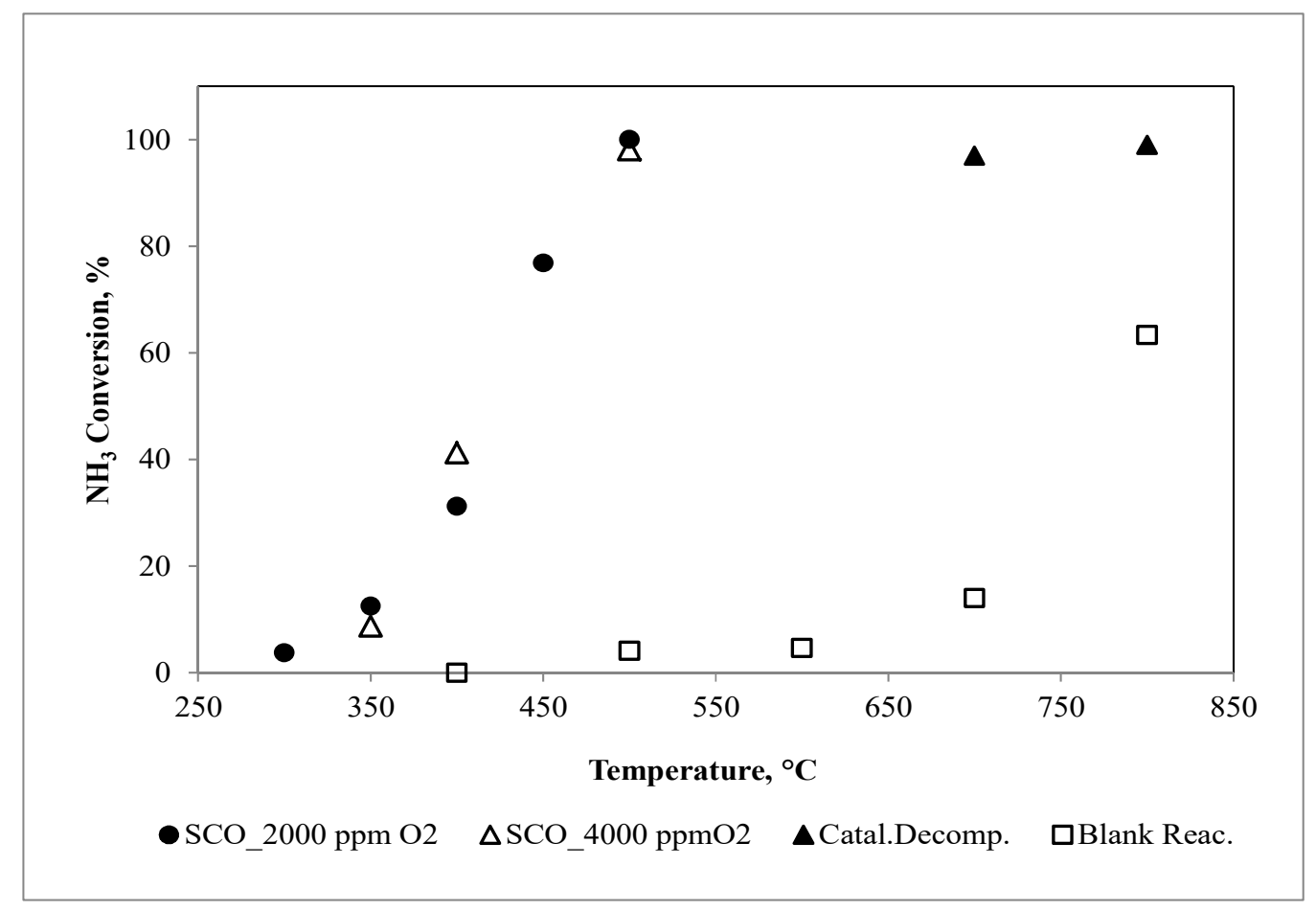

Figure 1: The change of $\mathrm{NH}_{3}$ conversion with temperature in $\mathrm{N}_{2}$ atmosphere at atmospheric pressure and $800 \mathrm{ppm}$ inlet $\mathrm{NH}_{3}$ concentration $\bullet$ Selective Catalytic Oxidation

(SCO) over Fe/HZ $\beta$ at 2000 ppm O $2 \Delta \mathrm{SCO}$ over $\mathrm{Fe} / \mathrm{HZ} \beta$ at 4000 ppm O $\mathrm{O}_{2} \mathbf{\Delta}$ catalytic decomposition over $\mathrm{Fe} / \mathrm{HZ} \beta \square$ blank reactor test without $\mathrm{O}_{2}$.

During the tests, $\mathrm{NO}_{x}$ and $\mathrm{H}_{2} \mathrm{O}$ concentrations in the reactor exit were followed by mass spectrometer as well. Figure 2 shows the $\mathrm{m} / \mathrm{z}$ peak intensities of these components ( $\mathrm{m} / \mathrm{z}=30$ for $\mathrm{NO} / \mathrm{NO}_{2}, \mathrm{~m} / \mathrm{z}=18$ for $\mathrm{H}_{2} \mathrm{O}, \mathrm{m} / \mathrm{z}=46$ for the fragment of $\mathrm{NO}_{2}, \mathrm{~m} / \mathrm{z}=44$ for $\mathrm{N}_{2} \mathrm{O}$ and $m / z=18$ for $\mathrm{H}_{2} \mathrm{O}$ ). It must be pointed out here that measuring the $\mathrm{NO}_{x}$ components with mass spectrometer have some difficulties because of the overlapping $\mathrm{m} / \mathrm{z}$ values at $\mathrm{m} / \mathrm{z}=30$ for $\mathrm{NO}$ and $\mathrm{NO}_{2}$. On the other, these measurements give an idea on the formation of $\mathrm{NO}_{x}$ components. As seen from the Figure 2, $\mathrm{NO}_{x}$ formation was apparent for all reaction temperature. As expected, water vapor was also formed upon Reactions $2-7$. The rate of water vapor formation was started decreasing at $500^{\circ} \mathrm{C}$ where $100 \%$ $\mathrm{NH}_{3}$ conversion was achieved. This was attributed to a possible secondary reaction between $\mathrm{NO}_{2}$ and $\mathrm{H}_{2} \mathrm{O}$ in the stoichiometric excess of $\mathrm{O}_{2}$ according to Reaction 9. On the other hand, further verifications are needed to make sure on the occurrence of this reaction.

$$
4 \mathrm{NO}_{2}(\mathrm{~g})+\mathrm{O}_{2}(\mathrm{~g})+2 \mathrm{H}_{2} \mathrm{O} \text { (vapor) } \rightarrow 4 \mathrm{HNO}_{3} \text { (vapor) }
$$




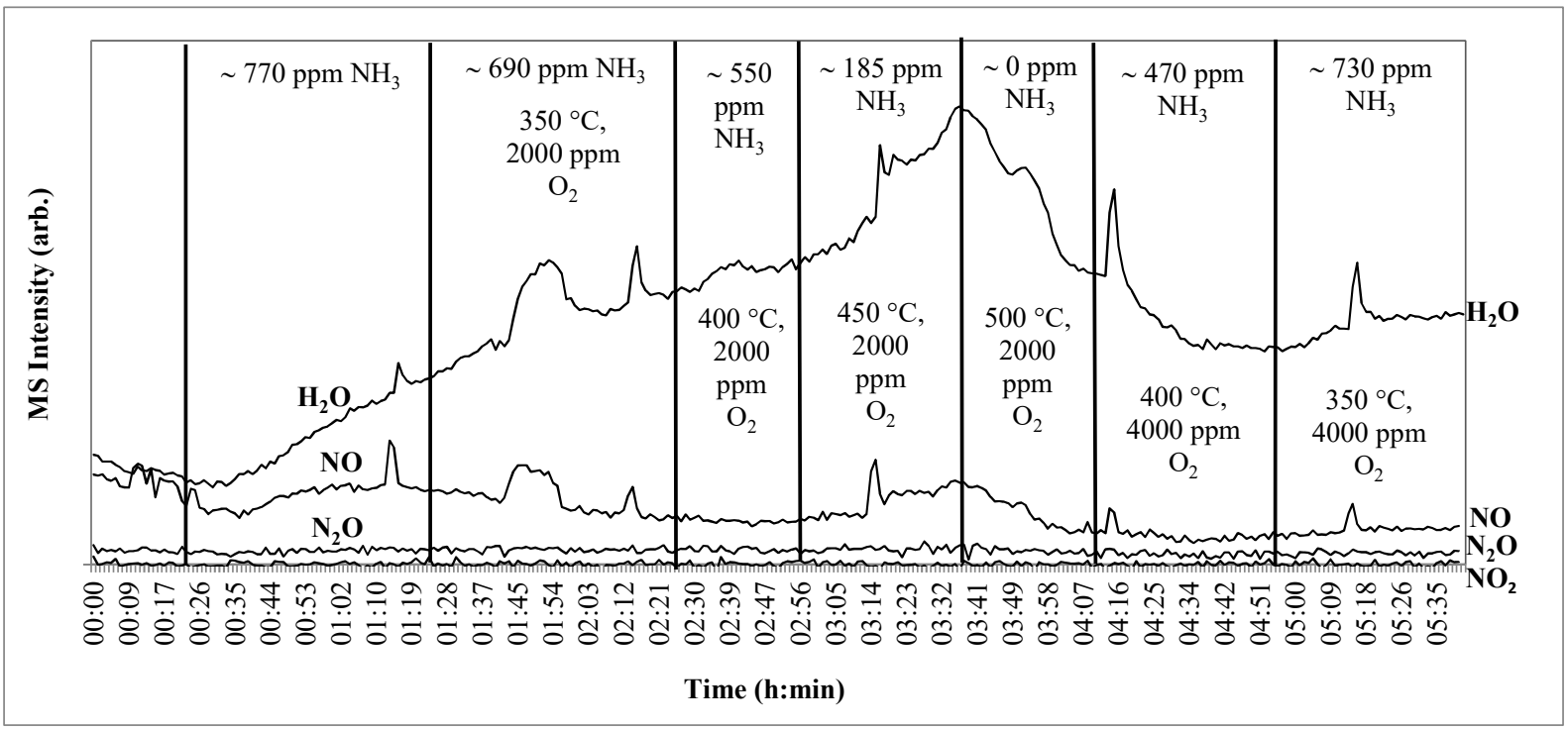

Figure 2: Effects of temperature and $\mathrm{O}_{2}$ amount on SCO of ammonia on $\mathrm{Fe} / \mathrm{HZ} \beta$ catalyst: MS data of $\mathrm{H}_{2} \mathrm{O}$ and $\mathrm{NO}_{x}$ in the reactor exit.

Unfortunately, mass spectrometric measurements did not let the selectivity and yield calculations due to the qualitative monitoring of $\mathrm{NO}_{x}$ components and excess $\mathrm{N}_{2}$ in the reaction atmosphere.

In the second set of catalytic decomposition of $\mathrm{NH}_{3}$ experiments, the reaction was intentionally carried out at high temperatures, namely at 700 and $800{ }^{\circ} \mathrm{C}$, due to the endothermic nature of the ammonia decomposition. Quite close conversions were achieved for 700 and $800{ }^{\circ} \mathrm{C}$ under nitrogen atmosphere by giving $\mathrm{H}_{2}$ and $\mathrm{N}_{2}$ as the decomposition products according to Reaction 1 . Thermodynamic equilibrium conversion of almost $100 \%$ was attained over both at 700 and $800{ }^{\circ} \mathrm{C}$ under nitrogen atmosphere.

In the last set of experiments, blank reactor tests were carried out under $\mathrm{NH}_{3}$ decomposition reaction conditions in the absence of $\mathrm{O}_{2} . \mathrm{NH}_{3}$ decomposition reaction started at $500{ }^{\circ} \mathrm{C}$ with a conversion of $4.1 \%$. The rate of $\mathrm{NH}_{3}$ decomposition reaction was seen to be increased after $700{ }^{\circ} \mathrm{C}$. While $\mathrm{NH}_{3}$ conversion was $14 \%$ at $700^{\circ} \mathrm{C}$, it was peaked to $63 \%$ at $800{ }^{\circ} \mathrm{C}$ where it was still below the value obtained over the catalyst.

It was shown that under $\mathrm{N}_{2}$ atmosphere, $100 \%$ of $\mathrm{NH}_{3}$ conversion was achieved over $\mathrm{Fe} / \mathrm{HZ} \beta$ catalyst through selective catalytic oxidation reaction at $500{ }^{\circ} \mathrm{C}$ while $94 \%$ of conversion was obtained over the same catalyst through the catalytic decomposition at $800^{\circ} \mathrm{C}$. These results indicated that while selective catalytic oxidation was promoted below $500{ }^{\circ} \mathrm{C}$, catalytic decomposition of $\mathrm{NH}_{3}$ to $\mathrm{H}_{2}$ and $\mathrm{N}_{2}$ was favored above $600{ }^{\circ} \mathrm{C}$.

To investigate the effect of $\mathrm{O}_{2}$ on $\mathrm{SCO}$ activity of $\mathrm{Fe} / \mathrm{HZ} \beta$ catalyst in detail, additional tests were conducted at both 400 and $500{ }^{\circ} \mathrm{C}$. SCO tests were carried out at changing $\mathrm{O}_{2}$ concentrations with an inlet gas composition of 800 ppmv $\mathrm{NH}_{3}$ in balance $\mathrm{N}_{2} . \mathrm{O}_{2}$ 
Durak-Çetin, Sarıoğlan and Okutan, JOTCSA. 2017; 4(1): 227-242. RESEARCH ARTICLE

concentrations were changed between $2000 \mathrm{ppm}$ and $6000 \mathrm{ppm}$. Obtained results are given in Figure 3. As it was seen in the Figure, conversions at $500{ }^{\circ} \mathrm{C}$ were slightly increased from $\sim 94 \%$ to $\sim 98 \%$ at increasing $\mathrm{O}_{2}$ concentrations. On the other hand, the highest ammonia conversion (41\%) at $400{ }^{\circ} \mathrm{C}$ was achieved with $4000 \mathrm{ppm} \mathrm{O}_{2}$. Relatively lower conversion values were observed with 2000 and 6000 ppm O2.This indicates that there seemed to be an optimal $\mathrm{O}_{2}$ concentration at $400^{\circ} \mathrm{C}$ for an acceptable surface adsorption and $\mathrm{NH}_{3}$ oxidation. $\mathrm{K}$. Duan et al. reported the similar case over $\mathrm{Cu}$ $\mathrm{Mn} / \mathrm{TiO}_{2}$ catalyst for $0.5 \%, 3 \%$ and $5 \% \mathrm{O}_{2}$ concentrations. In their study, the highest $\mathrm{NH}_{3}$ conversion ( $\% 85)$ was achieved in the presence of $3 \% \mathrm{O}_{2}$ at $250{ }^{\circ} \mathrm{C}$ [21]. This study supported the finding that there is an optimum $\mathrm{O}_{2}$ concentration related with temperature.

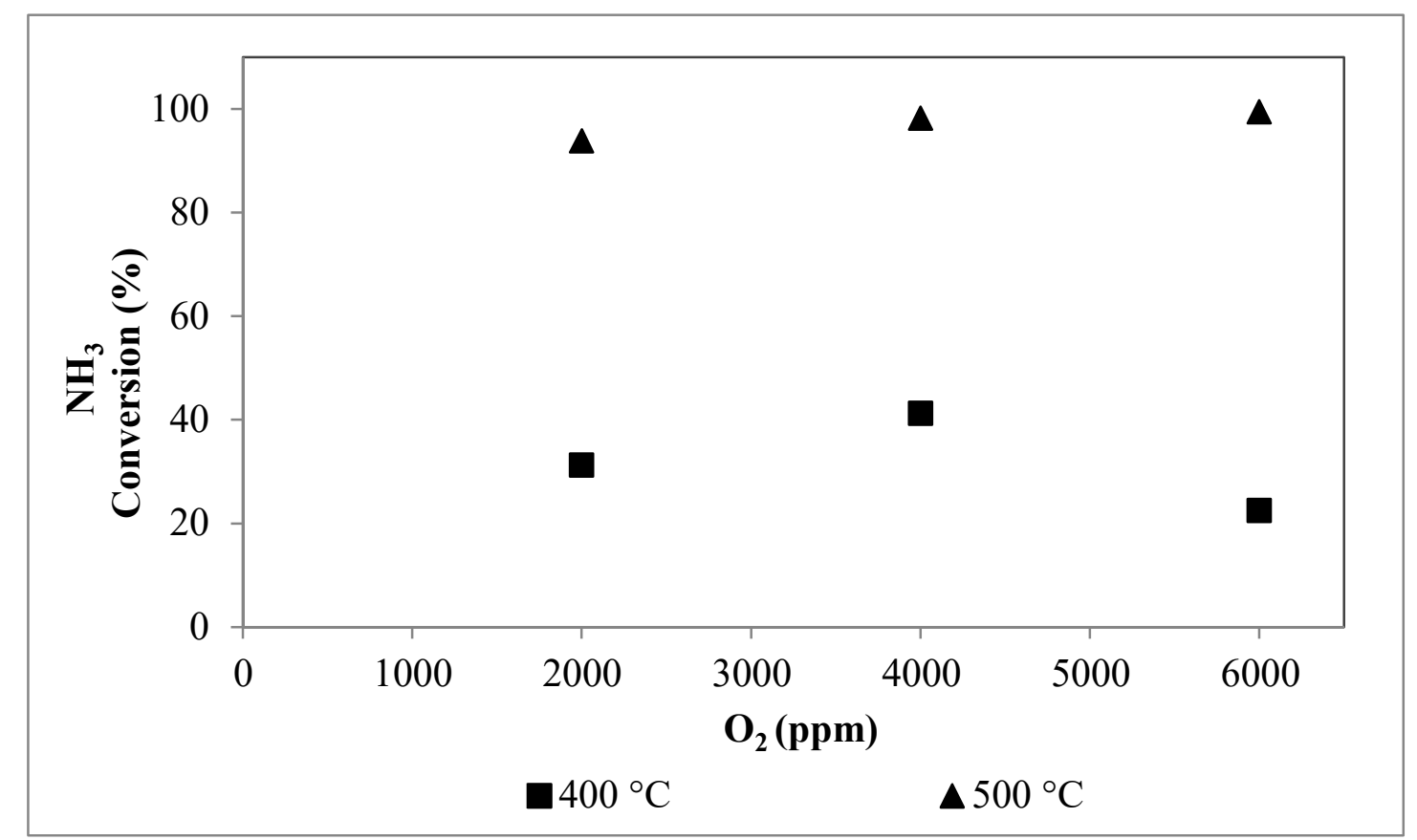

Figure 3: Effect of $\mathrm{O}_{2}$ concentration on ammonia conversion at 400 and $500{ }^{\circ} \mathrm{C}$.

To get the main picture of the catalytic decomposition and selective catalytic oxidation of ammonia results over $\mathrm{Fe} / \mathrm{HZ} \beta$ and in blank reactor, ammonia conversion values were also given in Table 1. 
Durak-Çetin, Sarıoğlan and Okutan, JOTCSA. 2017; 4(1): 227-242. RESEARCH ARTICLE

Table 1: The change of $\mathrm{NH}_{3}$ conversion with temperature and $\mathrm{O}_{2}$ amount without $\mathrm{H}_{2}$ at atmospheric pressure and $800 \mathrm{ppm}$ inlet $\mathrm{NH}_{3}$ concentration: Selective Catalytic Oxidation (SCO) and catalytic decomposition over $\mathrm{Fe} / \mathrm{HZ} \beta$

\begin{tabular}{|c|c|c|c|c|c|c|}
\hline & & \multicolumn{5}{|c|}{ Ammonia Conversion, \% } \\
\hline & & \multirow{2}{*}{$\begin{array}{c}\text { Ammonia } \\
\text { Decomposition } \\
0\end{array}$} & \multirow{2}{*}{$\begin{array}{c}\text { Blank } \\
\text { Reactor Test } \\
0\end{array}$} & \multicolumn{3}{|c|}{$\begin{array}{c}\text { Selective Catalytic } \\
\text { Oxidation of Ammonia }\end{array}$} \\
\hline \multirow{4}{*}{$\begin{array}{l}\mathrm{O}_{2} \text { amount } \\
(\mathrm{ppm})\end{array}$} & & & & 2000 & 4000 & 6000 \\
\hline & 300 & - & - & 4 & - & - \\
\hline & 350 & - & - & 13 & 9 & - \\
\hline & 400 & - & 0 & 31 & 41 & 23 \\
\hline \multirow{5}{*}{$\begin{array}{l}\text { Temperature } \\
\left({ }^{\circ} \mathrm{C}\right)\end{array}$} & 450 & - & - & 77 & - & - \\
\hline & 500 & - & 4 & 100 & 98 & 99 \\
\hline & 600 & - & 5 & - & - & - \\
\hline & 700 & 97 & 14 & - & - & - \\
\hline & 800 & 99 & 63 & - & - & - \\
\hline
\end{tabular}

In order to evaluate the selectivity of the reaction, gas samples were collected into the Tedlar bags after each test conducted at $500{ }^{\circ} \mathrm{C}$ and 2000, 4000 and $6000 \mathrm{ppm} \mathrm{O}$. Collected gas samples were analyzed with Analytic Jena multi EA ${ }^{\circledR} 5000$ Total Nitrogen (TN) measuring device equipped with Nitrogen Chemiluminescence Detector (NCD). $\mathrm{NO}_{x}$ concentrations of the samples were measured and results were drawn in Figure 4. As seen from the Figure, $\mathrm{NO}_{\mathrm{x}}$ concentration is linearly decreasing with increasing oxygen concentration. This might be due to the further oxidation of NO species according to Reaction 4 or $\mathrm{N}_{2} \mathrm{O}$ formation through Reaction 8 under excess oxygen atmosphere. Therefore, excess $\mathrm{O}_{2}$ might lead to the undesired $\mathrm{N}_{2} \mathrm{O}$ emissions.

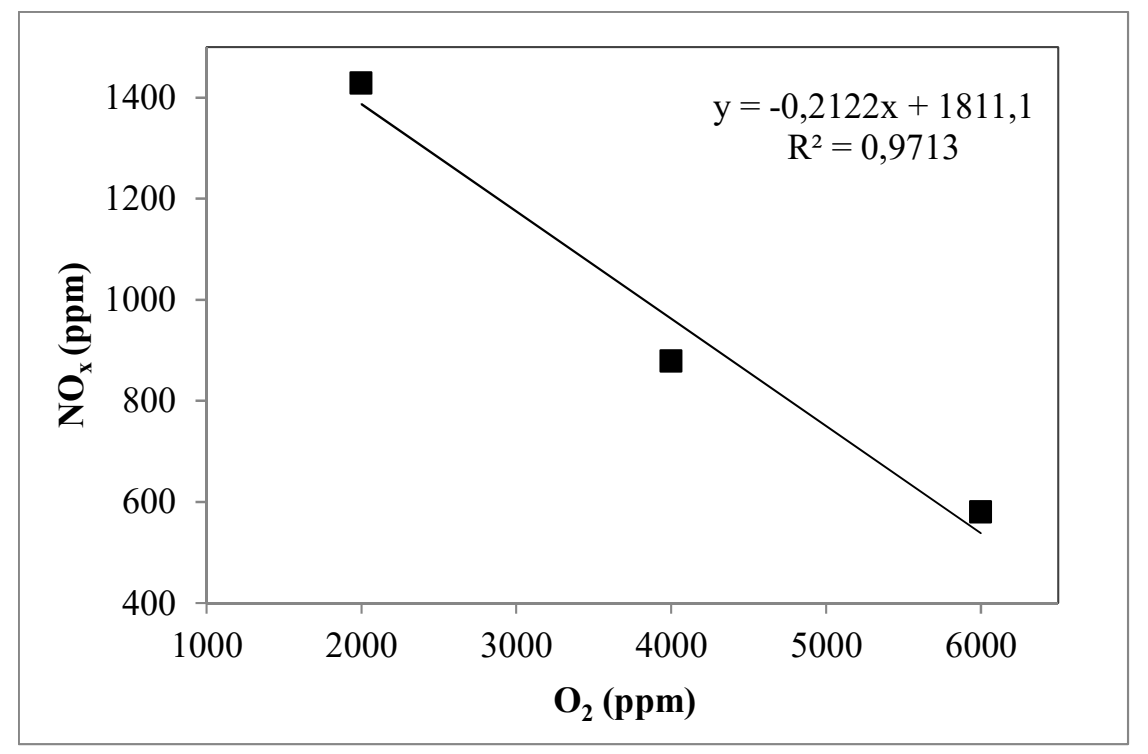

Figure 4: Effect of $\mathrm{O}_{2}$ concentration on $\mathrm{NO}_{x}$ exit from the $\mathrm{SCO}$ reactor at $500{ }^{\circ} \mathrm{C}$. 
Durak-Çetin, Sarıoğlan and Okutan, JOTCSA. 2017; 4(1): 227-242. RESEARCH ARTICLE

\section{Comparison of Catalytic Activities Under $\mathrm{H}_{2}$ Atmosphere}

$\mathrm{Fe} / \mathrm{HZ} \beta$ catalyst was pretreated in the way of the experimental work conducted under $\mathrm{N}_{2}$ atmosphere. Similarly, three sets of experiments were carried out, namely selective catalytic oxidation, catalytic decomposition and blank reactor test for decomposition. Selective catalytic oxidation (SCO) experiment was conducted with a gas mixture consisting of $4000 \mathrm{ppm} \mathrm{O}_{2}, 800 \mathrm{ppm} \mathrm{NH}, 10 \% \mathrm{H}_{2}$ and balance $\mathrm{N}_{2}$. The effect of reaction temperature on $\mathrm{NH}_{3}$ conversion was screened between 400 and $550^{\circ} \mathrm{C}$. The same gas mixture in the absence of $\mathrm{O}_{2}$ was flown over the reactor to carry out the catalytic decomposition of $\mathrm{NH}_{3}$ to $\mathrm{H}_{2}$ and $\mathrm{N}_{2}$ with or without catalyst. Decomposition reaction was tested at 700 and $800{ }^{\circ} \mathrm{C}$. Conversion results were plotted in Figure 5 and also given in Table 2. Contrary to the observation for SCO reaction under $\mathrm{N}_{2}$ atmosphere, $\mathrm{NH}_{3}$ conversions decreased with increasing reaction temperatures.

Figure 6 shows the trends for $\mathrm{H}_{2} \mathrm{O}$ formation and $\mathrm{O}_{2}$ consumption through the mass spectrometer. It is apparent that the main reaction product, $\mathrm{H}_{2} \mathrm{O}$, was formed at all reaction temperatures. On the other hand, its concentration decreased with concomitant increase in $\mathrm{O}_{2}$ concentration when the reaction temperature was decreased from $450{ }^{\circ} \mathrm{C}$ to $400{ }^{\circ} \mathrm{C}$. Although a decrease in reaction temperature and water vapor and an increase in $\mathrm{O}_{2}$ concentration, $\mathrm{NH}_{3}$ conversion was increased from $35 \%$ to $41 \%$. This is the clear indication of unselective oxidation of $\mathrm{H}_{2}$ at increasing temperatures. To clear the situation, $\mathrm{H}_{2}$ flow was cut from the mixture at $400{ }^{\circ} \mathrm{C}$ and it was shown that $\mathrm{H}_{2} \mathrm{O}$ concentration continued decreasing but the $\mathrm{NH}_{3}$ conversion remained the same. Therefore it was believed that $\mathrm{H}_{2}$ oxidation reaction competes with selective catalytic oxidation reaction of ammonia to $\mathrm{N}_{2}$ and $\mathrm{H}_{2} \mathrm{O}$.

$$
\begin{aligned}
& 4 \mathrm{NH}_{3}+3 \mathrm{O}_{2} \rightarrow 2 \mathrm{~N}_{2}+6 \mathrm{H}_{2} \mathrm{O}+302 \mathrm{kcal} \\
& 4 \mathrm{H}_{2}+2 \mathrm{O}_{2} \rightarrow 4 \mathrm{H}_{2} \mathrm{O}+231 \mathrm{kcal}
\end{aligned}
$$




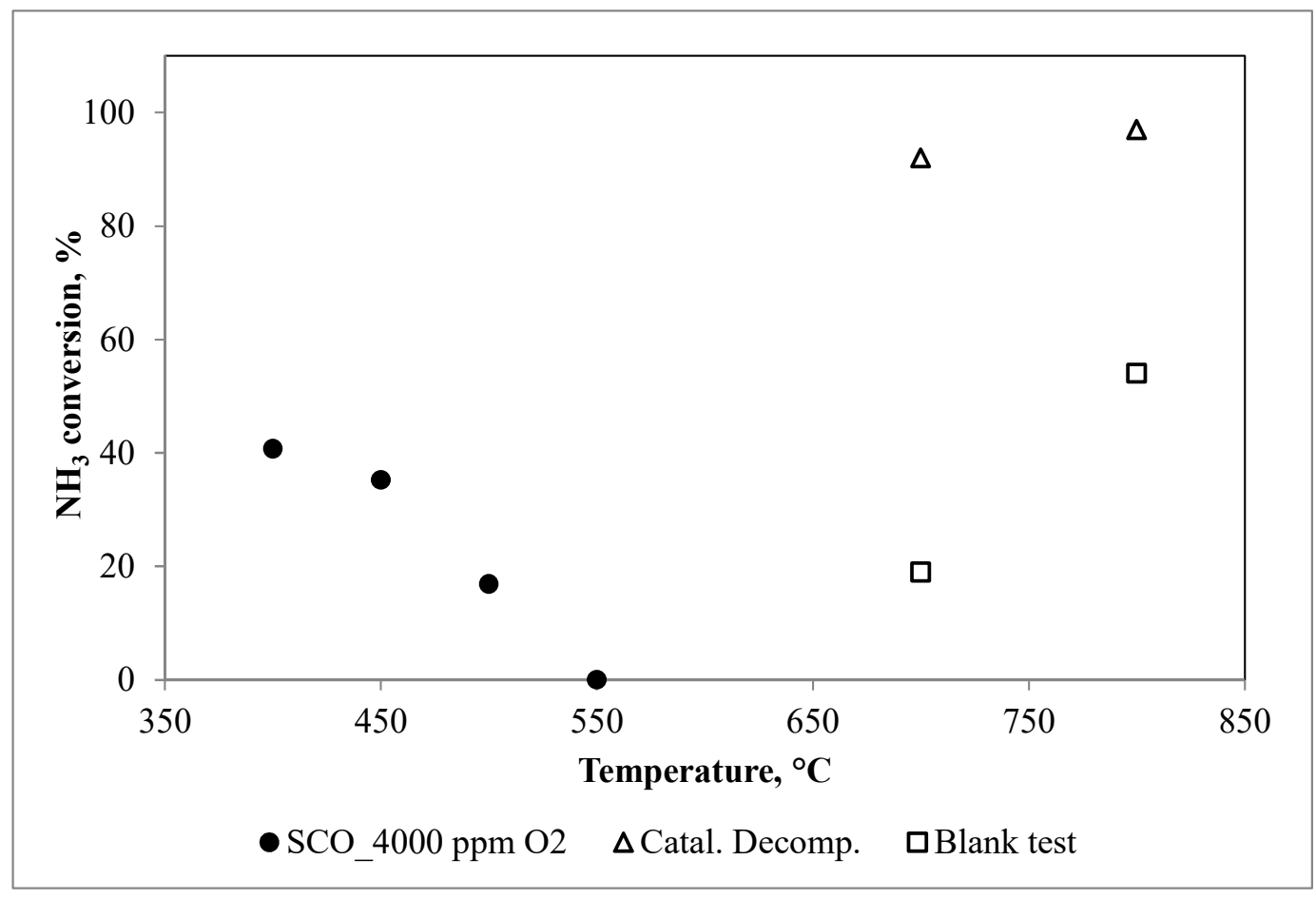

Figure 5. The change of $\mathrm{NH}_{3}$ conversion with temperature in $10 \% \mathrm{H}_{2}$ balance $\mathrm{N}_{2}$ atmosphere at atmospheric pressure and 800 ppm inlet $\mathrm{NH}_{3}$ concentration. • Selective Catalytic Oxidation over $\mathrm{Fe} / \mathrm{HZ} \beta \Delta$ Catalytic Decomposition over $\mathrm{Fe} / \mathrm{HZ} \beta$ घBlank reactor test without $\mathrm{O}_{2}$.

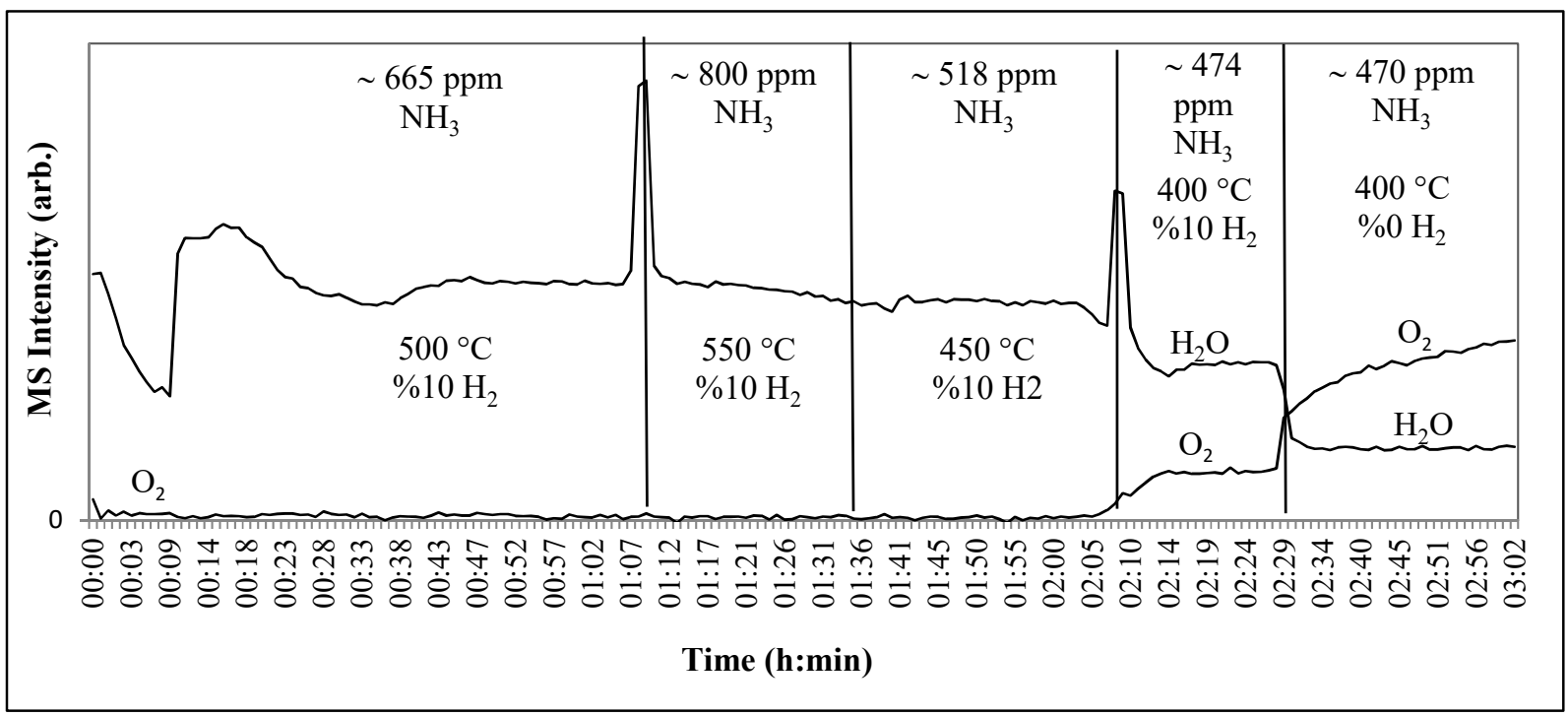

Figure 6: $\mathrm{H}_{2}$ effect on $\mathrm{SCO}$ of ammonia at different temperatures with $4000 \mathrm{ppm} \mathrm{O}_{2}$.

In the second case, catalytic decomposition of $\mathrm{NH}_{3}$ to $\mathrm{H}_{2}$ and $\mathrm{N}_{2}$ was tested under $10 \%$ $\mathrm{H}_{2}$ concentration. Although high $\mathrm{NH}_{3}$ conversions over $90 \%$ were achieved upon $\mathrm{H}_{2}$ addition, these conversions under $\mathrm{N}_{2}$ atmosphere were close to $100 \%$. For the third case, where catalytic decomposition of $\mathrm{NH}_{3}$ was tested without catalyst, it was seen that while $\mathrm{NH}_{3}$ conversion was $63 \%$ at $800^{\circ} \mathrm{C}$, it was decreased to $54 \%$ with $\mathrm{H}_{2}$ addition. On both 
Durak-Çetin, Sarıoğlan and Okutan, JOTCSA. 2017; 4(1): 227-242. RESEARCH ARTICLE

cases, loss of activity upon $\mathrm{H}_{2}$ addition was apparent. Therefore, a new set of experiments were conducted to investigate the effect of $\mathrm{H}_{2}$ concentration on the activity of $\mathrm{Fe} / \mathrm{HZ} \beta$ catalyst for $\mathrm{NH}_{3}$ decomposition. To do this, $\mathrm{H}_{2}$ concentration was changed between $10 \%$ and $30 \%$ for the same inlet $\mathrm{NH}_{3}$ concentration ( $800 \mathrm{ppm}$ ). Reactions were conducted at $700{ }^{\circ} \mathrm{C}$ and $800{ }^{\circ} \mathrm{C}$. The change of conversions with $\mathrm{H}_{2}$ concentration was plotted in Figure 7 and the corresponding conversion values were given in Table 2. It was shown that all conversions decreased. The decrease in conversion seemed to be linear with inlet hydrogen concentration. Hydrogen was seen to inhibit ammonia decomposition reaction. Conversion loss in the presence of hydrogen is reasonable for the dehydrogenation reactions regarding unfavorable thermodynamic conditions. On the other hand, competing kinetically relevant steps, namely $\mathrm{N}-\mathrm{H}$ bond breaking and atomic nitrogen association might also be responsible for this inhibition. Rate determining step might be $\mathrm{NH}_{3}$ dissociation due to hydrogen surrounding the active site [22]. Therefore, restricted $\mathrm{N}-\mathrm{H}$ bond breaking might limit the number of active sites to be occupied by $\mathrm{N}$ $\mathrm{N}$ pairs.

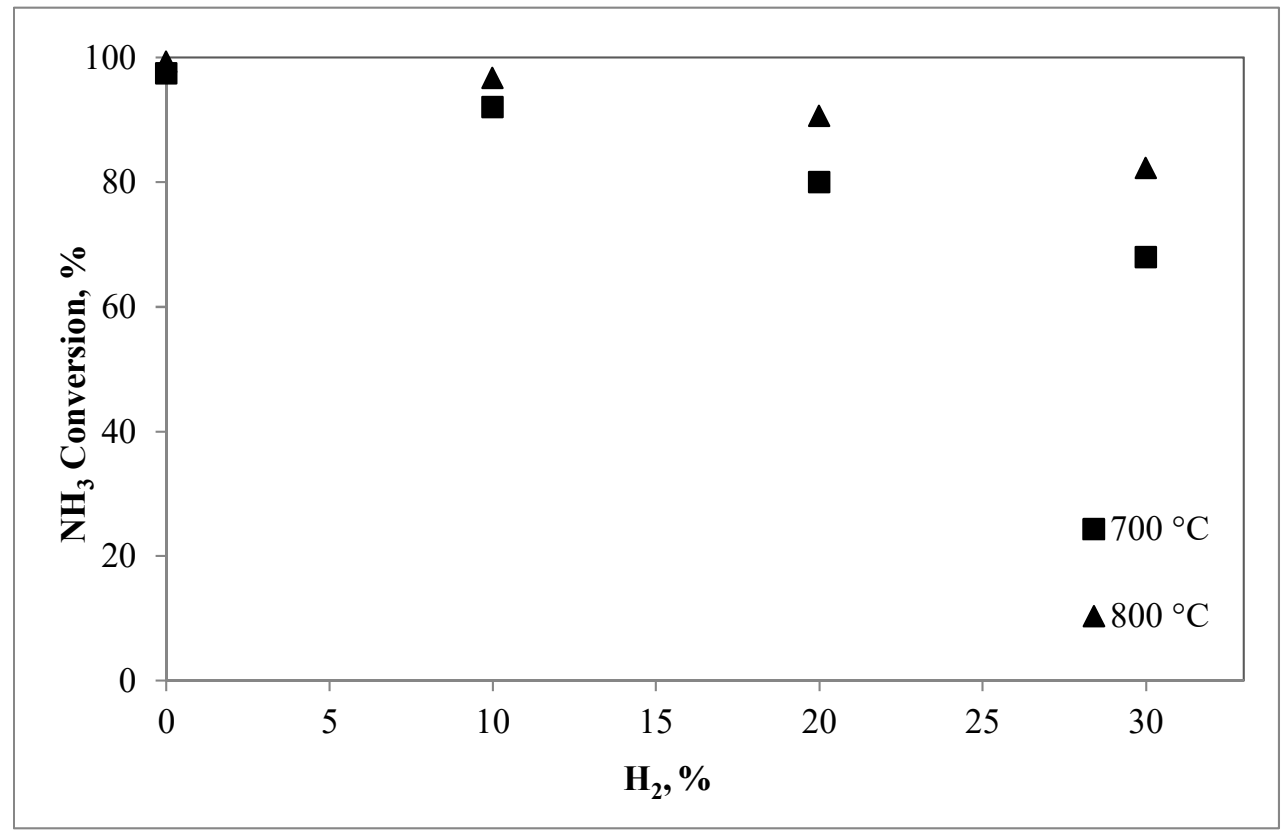

Figure 7: $\mathrm{NH}_{3}$ decomposition conversions changing with inlet $\mathrm{H}_{2}$ concentration at 700 and $800^{\circ} \mathrm{C}$. 
Durak-Çetin, Sarıoğlan and Okutan, JOTCSA. 2017; 4(1): 227-242. RESEARCH ARTICLE

Table 2: The change of $\mathrm{NH}_{3}$ conversion with temperature, $\mathrm{O}_{2}$ and $\underline{\mathrm{H}}_{2}$ amounts at atmospheric pressure and $800 \mathrm{ppm}$ inlet $\mathrm{NH}_{3}$ concentration: Selective Catalytic Oxidation (SCO) and catalytic decomposition over $\mathrm{Fe} / \mathrm{HZ} \beta$.

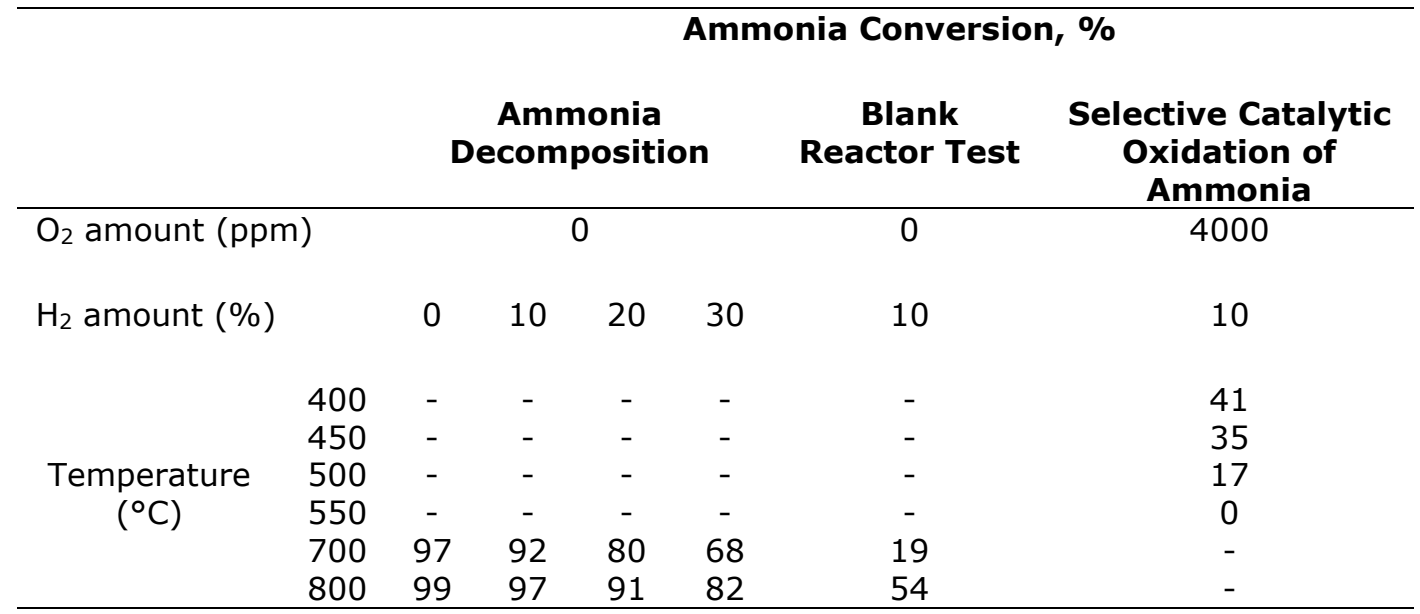

\section{CONCLUSIONS}

In this study, the catalytic activities over Zeolite $H \beta$ supported iron catalyst (Fe/HZ $\beta$ ) were compared both for the two catalytic routes, namely SCO and Catalytic Decomposition. It was shown that SCO of ammonia reaction is directly related with temperature and $\mathrm{O}_{2}$ amount. Although comparably higher conversions can be achieved under $\mathrm{N}_{2}$ atmosphere through SCO reaction, the presence of a fuel gas like $\mathrm{H}_{2}$ inhibits the selective oxidation of $\mathrm{NH}_{3}$ and leads to the poor conversions. The loss of SCO activity under $\mathrm{H}_{2}$ atmosphere was interpreted as the competing $\mathrm{H}_{2}$ and $\mathrm{NH}_{3}$ oxidations over the catalyst. On the other hand, although decomposition reaction of $\mathrm{NH}_{3}$ to $\mathrm{H}_{2}$ and $\mathrm{N}_{2}$ requires higher reaction temperatures, it was seen to be less sensitive to the presence of hydrogen. Activity loss with $\mathrm{H}_{2}$ addition in the case of decomposition reaction was considered to be due to both unfavorable thermodynamic conditions for dehydrogenation and restricted $\mathrm{N}-\mathrm{H}$ bond breaking due to the hydrogen surrounding the active sites.

\section{ACKNOWLEDGMENTS}

The authors greatly acknowledge to "The Scientific and Technological Research Council of Turkey (TÜBİTAK)" for supporting of "Liquid Fuel Production from Biomass and Coal Blends" project (Contract Code: 108G043) in which this study was carried out. The authors would also like to thank the State Planning Organization of Turkey for their 
Durak-Çetin, Sarıoğlan and Okutan, JOTCSA. 2017; 4(1): 227-242. RESEARCH ARTICLE

laboratory infrastructure funding (Project: Excellency Center for Gas Technologies, 2011K120040).

\section{REFERENCES}

1. Basu, P. (2006). Combustion and Gasification in Fluidized Beds, Taylor \& Francis Group, LLC.

2. Rönkkönen, H., Simell, P., Reinikainen, M., Krause, O. ve Niemela, M.V., (2010). Catalytic cleanup of gasification gas with precious metal catalysts - A novel catalytic reformer development, Fuel, 89, 3272-3277. DOI: 10.1016/j.fuel.2010.04.007.

3. Xu C., Donald J., Byambajav E., Ohtsuka Y., (2010). Recent Advances in Catalysts for Hot Gas Removal of Tar and NH3 from Biomass Gasification, Fuel, 89, 1784-1795. DOI:

10.1016/j.fuel.2010.02.014.

4. Hongrapipat J, Saw W.L, Pang S. Removal of Ammonia from Producer Gas in Biomass Gasification: Integration of Gasification Optimisation and Hot Catalytic Gas Cleaning. Biomass Conversion and Biorefinery. 2012, 2 (4), 327-348. DOI: 10.1007/s13399-012-0047-1.

5. Hu J, Yu F, Lu Y. Application of Fischer-Tropsch Synthesis in Biomass to Liquid Conversion. Catalysts. 2012; 2(2), 303-326; DOI: 10.3390/catal2020303.

6. Durak-Çetin Y, Sarığlan A, Sarıoğlan Ş, Okutan H. The Effect of Support Type on the Activity of Zeolite Supported Iron Catalysts for the Decomposition of Ammonia. Reaction Kinetics, Mechanisms and Catalysis. 2016; in press, DOI: 10.1007/s11144-016-0981-1.

7. Pansare SS, Torres W, Goodwin J G. Ammonia decomposition on tungsten carbide. Catalysis Communications. 2007;8:4, 649-654. DOI: 10.1016/j.catcom.2006.08.016.

8. Zheng W, Zhang J, Xu H. NH3 Decomposition Kinetics on Supported Ru Clusters: Morphology and Particle Size Effect. Catalysis Letters. 2007;119:3, 311-318. DOI: 10.1007/s10562-007-9237$z$.

9. Leppalahti J, Simell P, Kurkela E. Catalytic conversion of nitrogen compounds in gasification gas. Fuel Processing Technology. 1991; 29:1-2, 43-56.

10. Ohtsuka Y, Xu C, Kong D, Tsubouchi N. Decomposition of ammonia with iron and calcium catalysts supported on coal chars. Fuel. 2004 83:6, 685-692. DOI:10.1016/j.fuel.2003.05.002.

11. Donald J, Xu CC, Hashimoto H, Byambajav E, Ohtsuka Y. Novel carbon-based Ni/Fe catalysts derived from peat for hot gas ammonia decomposition in an inert helium atmosphere, Applied Catalysis A: General. 2010; 375:1, 124-133. DOI:10.1016/j.apcata.2009.12.030.

12. Simell $P$, Kurkela $E$, Stahlberg $P$, Hepola J. Catalytic hot gas cleaning of gasification gas. Catalysis Today. 1996; 27(1-2):55-62. DOI:10.1016/0920-5861(95)00172-7.

13. Tsubouchi N, Hashimoto H, Ohtsuka Y. High Catalytic Performance of Fine Particles of Metallic Iron Formed from Limonite in the Decomposition of a Low Concentration of Ammonia. Catalysis Letters. 2005; 105(3-4):203-208. DOI: 10.1007/s10562-005-8691-8.

14. Xu C, Tsubouchi N, Hashimoto $\mathrm{H}$, Ohtsuka $\mathrm{Y}$. Catalytic decomposition of ammonia gas with metal cations present naturally in low rank coals. Fuel. 2005; 84:14-15, 1957-1967. DOI:

10.1016/j.fuel.2005.03.019.

15. Jabłońska M, Chmielarz L, Węgrzyn A. Selective catalytic oxidation (SCO) of ammonia into nitrogen and water vapor over hydrotalcite originated mixed metal oxides: a short review. 
Durak-Çetin, Sarıoglan and Okutan, JOTCSA. 2017; 4(1): 227-242. RESEARCH ARTICLE

CHEMIK. 2013; 67, 8, 701-710. YADDA identifier: bwmeta1.element.baztech-6167861c-0171499d-b857-8e5d837c4b2f.

16. Torres W, Pansare S S, Goodwin J G. Hot Gas Removal of Tars, Ammonia, and Hydrogen Sulfide from Biomass Gasification Gas. Catalysis Reviews: Science and Engineering. 2007; 49, 4, 407-456. DOI: 10.1080/01614940701375134.

17. Shioya Y, Miyaki Y, Ammonia decomposition catalyst and process for decomposition of ammonia using the catalyst. European patent application. 2009; EP1872852A1.

18. Long R Q, Yang R T. Selective Catalytic Oxidation (SCO) of Ammonia to Nitrogen over FeExchanged Zeolites. Journal of Catalysis. 2001; 201, 145-152. DOI: 10.1006/jcat.2001.3234.

19. Kurkela E, Kurkela M. Advanced Biomass Gasification for High Efficiency Power, Final Activity Report of BIGPower Projec. VTT Research Notes 2511, ISBN 978-951-38-7537-4 (URL: http://www.vtt.fi/publications/index.jsp); 2009.

20. Baranak M, Gürünlü B, Sarıoğlan A, Ataç Ö, Atakül H. Low acidity ZSM-5 supported iron catalysts for Fischer-Tropsch synthesis. Catalysis Today 2013;207:57-64. DOI: 10.1016/j.cattod.2012.04.013.

21. Duan K, Tang X, Yi H, Ning P, Wang L. Rare earth oxide modified Cu-Mn compounds supported on $\mathrm{TiO}_{2}$ catalysts for low temperature selective catalytic oxidation of ammonia and in lean oxygen. Journal of Rare Earths, Dec.2010; 28, 338-342. DOI: 10.1016/S1002-0721(10)60277-3.

22. Guo W, Vlachos DG. Patched bimetallic surfaces are active catalysts for ammonia decomposition. Nature Communications 2015; 6:8619. DOI: 10.1038/ncomms9619. 


\title{
Türkçe Öz ve Anahtar Kelimeler
}

\section{Fe/HZß Katalizörü Üzerinde Amonyağın Seçici Katalitik Yükseltgenme ve Bozunma Aktivitelerinin Karşılaştırılması}

\begin{abstract}
Yeliz Durak-Çetin, Alper Sarıoğlan, Hasancan Okutan
Öz: Amonyak, sentez gazı kullanılmadan önce giderilmesi gereken sentez gazı kirleticilerinden biridir. Amonyağın en umut vaat eden sıcak gaz temizleme yöntemi seçici katalitik yükseltgeme (SCO) ve katalitik bozunmadır. Bu çalışmada; Zeolit $\mathrm{H} \beta$-destekli demir katalizör $(\mathrm{Fe} / \mathrm{HZ} \beta)$ üzerindeki amonyak giderim aktiviteleri iki katalitik yol için de karşılaştırılmıştır. SCO deneyleri için, sıcaklık (300-550 $\left.{ }^{\circ} \mathrm{C}\right), \mathrm{O}_{2}(2000-6000 \mathrm{ppmv})$ ve $\mathrm{H}_{2}$ (\%0-10) konsantrasyonlarının etkisi her gaz karışımında $800 \mathrm{ppm} \mathrm{NH}_{3}$ olacak şekilde incelenmiştir. İkinci yolda ise, katalitik amonyak bozunma denemeleri $\mathrm{N}_{2}$ içinde $\mathrm{H}_{2}(\% 0-$ 30) varlığında 800 ppm NH 3 içeren gaz karışımı ile 700 ve $800{ }^{\circ} \mathrm{C}$ 'de gerçekleştirilmiştir. SCO'da, $\mathrm{NH}_{3}$ dönüşümlerinin reaksiyon ortamında $\mathrm{H}_{2}$ olmadığı durumda artan reaksiyon sıcaklığı ile arttığı görülmüştür. $\% 10 \mathrm{H}_{2}$ varlığında ise, azalan reaksiyon sıcaklığı ile $\mathrm{NH}_{3}$ dönüşümlerinin arttığı tespit edilmiştir. Bu durum katalizör üzerinde $\mathrm{H}_{2}$ ve $\mathrm{NH}_{3}$ yükseltgenmesinin yarışmalı olarak gerçekleştiği şeklinde yorumlanmıştır. Diğer taraftan, katalitik bozunma reaksiyonunda, hem 700 ve hem de $800{ }^{\circ} \mathrm{C}$ 'de termodinamik denge dönüşümüne yakın, yaklaşık \%100, amonyak dönüşümleri elde edilmiştir. Ortama $\mathrm{H}_{2}$ ilavesi ile bütün dönüşümlerde azalma görülmüştür. Dönüşümlerdeki azalma giriş hidrojen konsantrasyonu ile doğrusal bir iliş̧ki göstermiştir. Hidrojenin, amonyağın bozunma reaksiyonunu engellediği görülmüştür. $\mathrm{Fe} / \mathrm{HZ} \beta$ katalizörünün, sentez gazındaki $\mathrm{NH}_{3}$ 'ün giderilmesinde $\mathrm{NH}_{3}$ 'ün seçici katalitik yükseltgenmesinden ziyade, daha yüksek sıcaklıklara ihtiyaç duyulmasına rağmen $\left(700-800{ }^{\circ} \mathrm{C}\right)$, amonyak bozunma reaksiyonunda kullanılmasının daha etkili olacağı gösterilmiştir.
\end{abstract}

Anahtar kelimeler: Amonyak; bozunma; seçici katalitik yükseltgeme (SCO); sıcak gaz temizleme.

Sunulma: 01 Temmuz 2016. Düzeltme: 11 Kasım 2016. Kabul: 18 Kasım 2016. 